\title{
DESIGN \& ANALYSIS OF NEEDLE ROLLER BEARING AT GUDGEON PIN OF GINNING MACHINE
}

\author{
P.A.Chandak ${ }^{1}$, A.D.Thakare ${ }^{2}$, S.P.Untawale ${ }^{3}$, G.R.Nakhale ${ }^{4}$ \\ ${ }^{1}$ Assistant professor, Mechanical Engineering Department, DMIETR Wardha, Maharashtra, India \\ ${ }^{2}$ M-Tech students, Mechanical Engineering Department, DMIETR Wardha, Maharashtra, India \\ ${ }^{3}$ Principal, Mechanical Engineering Department, DMIETR Wardha, Maharashtra, India \\ ${ }^{4}$ Lecturer, Mechanical Engineering Department, PRP POLYTECHNIC talegaon (s.p.), Maharashtra, India
}

\begin{abstract}
Needle roller bearings have high load carrying capacity although it have small cylindrical roller having low cross section, thus it used in application where space limitation is the important factor along with high dynamic loading capacity. So in ginning machine where space is limited for driving the mechanism a Needle roller bearing having diameter of 20 mm is used in between connecting rod and head pin to give the relative motion between parts. As the continuous impacting of repetitive load on bearing, it fails with in shorter period of time if proper lubricant is not supplied by grease gun after 2 to 3 hours. While bearing are considered under observation it is found that bearing are fail due to brinnelling. So design and analysis of needle roller bearing is vital to calculate the life of bearing and to make sure whether this bearing is suitable or not. So it becomes mandatory in designing to calculate radial load applied on bearing as the bearing is rolling contact bearing, from this life of the bearing can be calculated and finally analysis by ANSYS software is done to find the result so that we can conclude for bearing.
\end{abstract}

Key Words: brinneling, connecting rod, dynamic load capacity, head pin, life, radial load, repetitive load.

\section{INTRODUCTION}

At M.R. Ginning and pressing factory, Talegaon (S.P.) where 20 double roller ginning machine are working continuously for 24 hours, breakdown or stopping of machine is the major problem for production. Varieties of cotton purchase from farmers are sending to the ginning machine through conveyor system which is fully automatic. A quantity of cotton to be feed is managed by auto feeder which is mounted on the top side of the ginning machine. Cotton which is supplied by auto feeder to the beater shaft assembly which is oscillating about $1179 \mathrm{rpm}$, calculated value from relative velocity method. This beater shaft assembly is drives by $5 \mathrm{HP}$ motor, which gives power to the eccentric shaft. From eccentric shaft on one side power is transmitted to the gear train and on another side to the connecting rod, head block and beater shaft. Gear train are used to drive the leather chrome roller whose function is to adhere with lint and carried forward to the downside. Eccentric motion to the connecting rod then to head block in between this to have relative motion a needle roller bearing (RNA6902) are placed with gudgeon pin. Fig 1.1 shows the line diagram of ginning machine.

After the discussion carried out at M.R. Ginning and Pressing factory related to performance of machine, it was found that bearings used in between connecting rod and head pin which is inserted in headlock is needle roller bearing having specification RNA 6902 get fails within 3 to 4 hours if lubricant not provided properly, even it having higher dynamic load capacity.
The oscillation of beater shaft assembly is for detaching the fiber from seed of the cotton. A moving knife which is attached with the assembly oscillates with $1179 \mathrm{rpm}$ and time required for one oscillation is $0.0245 \mathrm{sec}$. and energy required for detaching fiber is around 2800 joule $/ \mathrm{kg}$ of lint and it varies from condition and varieties of cotton [ ]. So this kinetic energy of rotating masses results in excessive load on bearing which causes plastic deformation of the cage called brinelling. The various parts of ginning machine of M. R. Ginning and Pressing factory are shown in figure 1.2.In the present work failure analysis of Needle roller bearing having dynamic load capacity of $17.3 \mathrm{KN}$ is done.

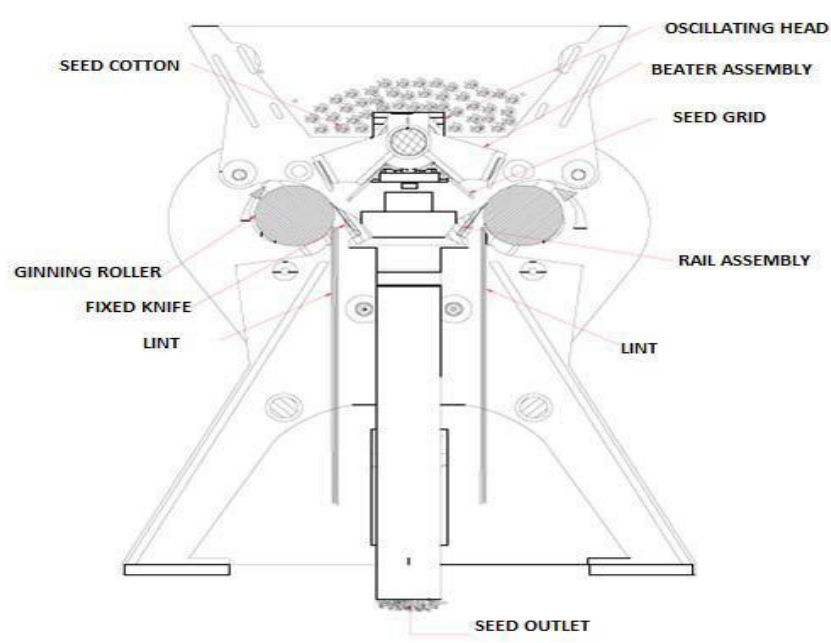

Fig -1: Line diagram of ginning machine 


\section{WORKDONE}

5HP motor drives the hub of machine by using belt drives. An eccentric shaft is mounted inside of the hub which rotate with same speed of hub, on one side of eccentric shaft pinion gear is mounted which drives the gear train result in rotation of leather chrome roller. Also on another side eccentricity is provided on eccentric shaft which work like crank on which connecting rod is mounted at big end and at another side on small end head pin is attached with the help of needle roller bearing with gudgeon pin, result in oscillation of head block which drives the beater shaft assembly. Beater shaft assembly's function is to detach the fiber from cotton with the help of moving knife. According to prof. P. G. Patil and Prof P. M. Padole and S. B. Jadhao and K. M. Parlikar gives information about energy required for detaching the fiber from the seed, observed wide variation among the different varieties of cotton and relates to the strength of attachment of fiber from the seed. This is about $2800 \mathrm{j} / \mathrm{kg}$ of lint. Fig $2 \& 3$ shows the double roller ginning machine and its components.

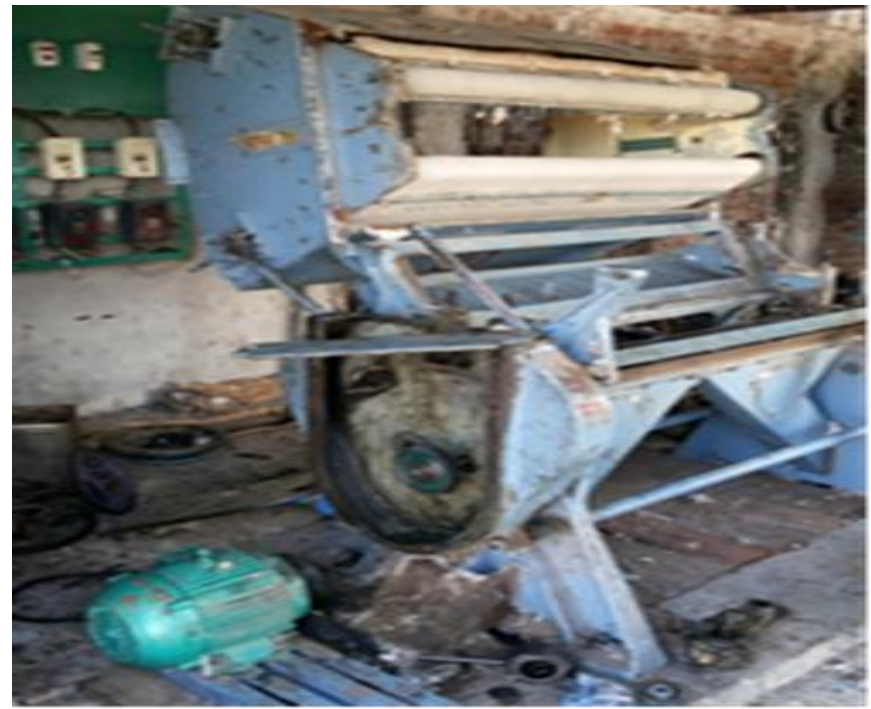

Fig -2: Double roller ginning machine

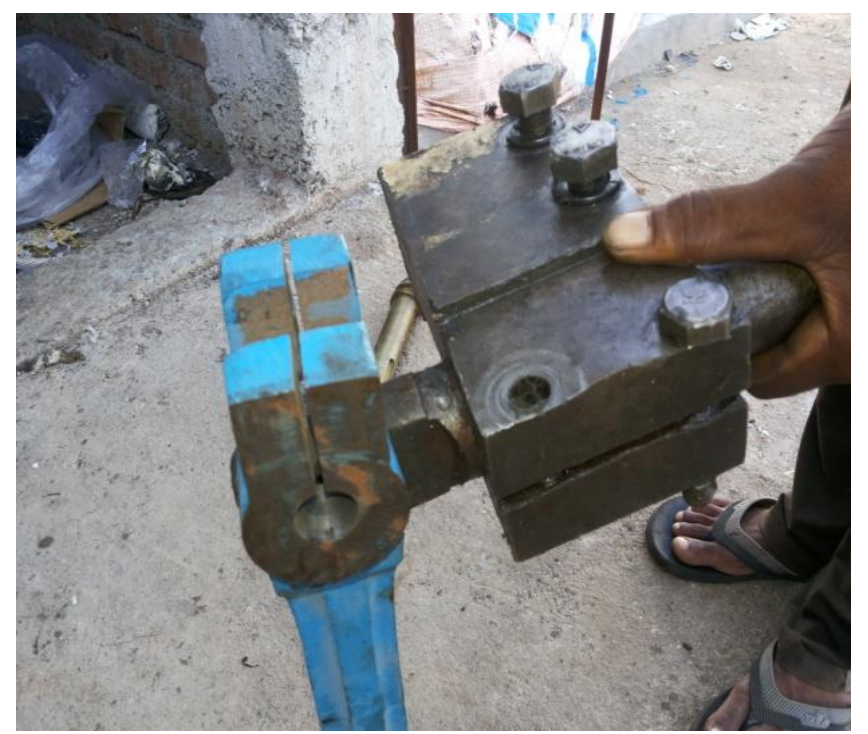

Fig -3: Component drive by needle roller bearing

\section{FAILURE OF NEEDLE ROLLER BEARING AT GUDGEON PIN}

Needle roller bearings (of type RNA6902) are used in ginning machine because of higher dynamic load capacity. Fig 4.shows detailed terminology of bearings.

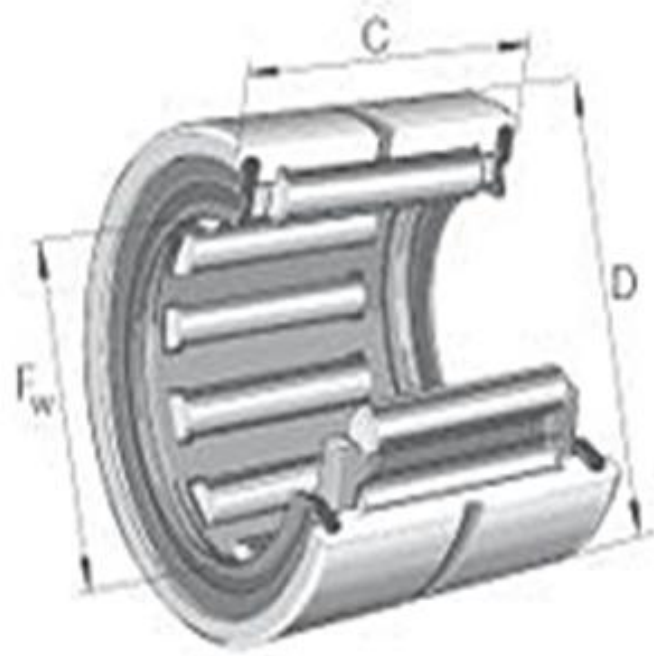

Fig -4: Needle roller bearing

Where,

C - Width of Bearing,

D - Outside diameter of RING

Fw - Diameter under rollers

A Double roller ginning machine work on the principle of eccentric motion from eccentric shaft converted into oscillating motion of the beater shaft assembly, needed for continuous beating of cotton comes in between moving knife and fixed knife in order to detach fiber from the cotton. A Needle roller bearing is fixed in head pin with interference. A gudgeon pin is used to connect head pin with connecting rod and relative motion between them is done by this bearing.

Table -1: Needle roller bearing RNA (6902) terminology

\begin{tabular}{|c|c|c|c|c|c|c|c|c|c|}
\hline \multicolumn{3}{|c|}{ 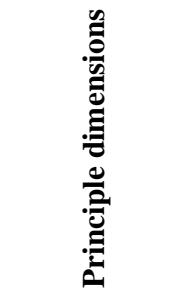 } & \multicolumn{2}{|c|}{ 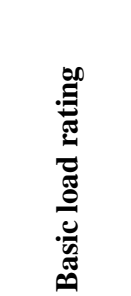 } & 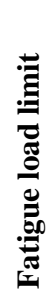 & \multicolumn{2}{|c|}{ 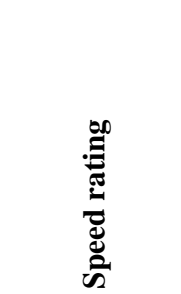 } & \multirow[t]{2}{*}{ 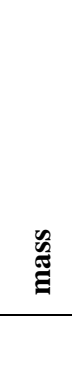 } & \multirow[t]{2}{*}{ 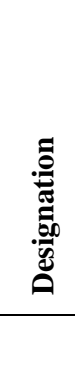 } \\
\hline Fw & D & $\mathbf{C}$ & $\mathbf{C}$ & Co & & $\begin{array}{l}\text { Ref } \\
\text { speed }\end{array}$ & $\begin{array}{l}\text { Lim } \\
\text { speed }\end{array}$ & & \\
\hline \multicolumn{3}{|l|}{$\mathbf{m m}$} & \multicolumn{2}{|l|}{ KN } & KN & \multicolumn{2}{|l|}{$\mathrm{r} / \mathrm{min}$} & kg & \\
\hline 20 & 28 & 23 & $\mathbf{1 7 . 3}$ & 27 & 3.4 & 19000 & 22000 & 0.040 & $\begin{array}{l}\text { RNA } \\
6902\end{array}$ \\
\hline
\end{tabular}


A needle roller bearing (RNA6902) having dynamic capacity of $17300 \mathrm{~N}$ taking reference from NSK bearing catalogue are subjected to a repetitive heavy load. As this is rolling element bearing it is subjected to radial load, according to company specification it is need to be lubricated after every 2 hours so the life of bearing is too small. So it becomes necessary to calculate the life of the bearing. Also need to find out the actual load to be imparted on the bearing which results in failure.

Load acting on the bearing are calculated by taking into account all static load on bearing. Load acting by inertia masses which rotate with respect to bearing and force required to detach the fiber from seed. In order to find the load acting on the bearing we have data by prof. P. G. Patil and Prof P. M. Padole. And S. B. Jadhao and K. M. Parlikar gives information about energy required for detaching the fiber from the seed, observed wide variation among the different varieties of cotton, and related it to the strength of attachment of fiber from the seed. This is about $2800 \mathrm{j} / \mathrm{kg}$ of lint.

The needle roller bearing investigated for failure of bearing. It is found that cage of the bearing are subjected to plastic deformation and also needle are sleep out from cage contact. This is due to high impact load acting on the bearing and such type failures are brinneling failure.

\section{RADIAL LOAD CALCULATION}

For finding radial load on bearing which is fitted on head pin and it is mounted on head block, as head block oscillates it gives motion to the beater shaft assembly. This beater shaft assembly and head block along with head pin work as a fulcrum. So it becomes necessary to calculate torque on beater shaft which useful in calculating radial load on bearing.

\section{Torque transmitted by beater shaft :}

$\mathrm{T}=\mathrm{I} \alpha$

Where,

T = Torque in $N-m$

$\mathrm{I}=$ moment of inertia of rotating masses $\mathrm{Kg}-\mathrm{m}^{2}$

$\alpha=$ angular acceleration $\mathrm{rad} / \mathrm{sec}^{2}$

Radial load $\left(\mathbf{F}_{\mathbf{r}}\right)$ :

$T=F t \times r$

Where,

$\mathrm{T}=$ torque on beater shaft

$\mathrm{Ft}=$ theoretical Radial load on bearin $\mathrm{R}=$ radius of head pin from axis of beater shaft

From the above calculation for calculating the radial load acting on the bearing a torque on the beater shaft need to be calculated which is undergoes various rotating amd inertia masses. A head block which oscillates the beater shaft assembly considered as a fulcrum whose radial distance is $0.155 \mathrm{~m}$ from bearing. Radial load on the bearing is calculated as $6.5 \mathrm{KN}$.

\section{BEARING LIFE}

Bearing load $\left(\mathbf{F}_{\mathrm{r}}\right)$ :

The load applied on the bearing generally include the weight of the body to be supported by the bearing, the weight of the revolving element themselves, the transmission power of gears and belting, the load produced by the operation of the machine in which the bearing are used, etc. These load are theoretically calculated, but some of them difficult to estimate.

\section{Load factor $(L f)$ :}

When radial or axial load has been mathematically calculated, the actual load on the bearing may be greater than calculated load because of vibration and shock present during operation of the machine. The actual load can be calculated using the following equation:

$$
F r=L f \times F t
$$

Where,

$F r=$ load applied on the bearing $L f=$ load factor (values from NSK bearing catalogue)

$F t=$ Theoretically calculated load

\section{Equivalent Bearing Load P (KN):}

$\mathrm{P}=\left(\mathrm{XF}_{\mathrm{r}}+\mathrm{YF}_{\mathrm{a}}\right) \mathrm{K}_{\mathrm{g}} \mathrm{K}_{\mathrm{o}} \mathrm{K}_{\mathrm{r}}$

(Values taken from NSK bearing catalogue)

Where,

$\mathrm{F}_{\mathrm{r}}=\operatorname{Radial} \operatorname{Load}(\mathrm{KN})$

$\mathrm{F}_{\mathrm{a}}=$ Axial Load $(\mathrm{KN})$

$\mathrm{X}, \mathrm{Y}=$ Constant for bearing selected from table

$\mathrm{K}_{\mathrm{s}}=$ Service Factor

$\mathrm{K}_{\mathrm{O}}=$ Oscillation Factor

$\mathrm{K}_{\mathrm{r}}=$ Rotational Factor

(All values of factors selected from design data book table )

\section{Life of Bearing:}

$\mathrm{L}=\left(\frac{\mathrm{C}}{\mathrm{P}}\right)^{\mathrm{n}} * \mathrm{~K}_{\mathrm{ret}}$

Where,

$\boldsymbol{L}=$ Life in million cycles

$\mathrm{C}=$ Dynamic load capacity $(\mathrm{KN})$

$\mathrm{P}=$ Equivalent Bearing Load $(\mathrm{KN})$

$\mathrm{n}=3.33$ for roller bearing

$\mathrm{K}_{\mathrm{ret}}=$ Reliability factor select from table

\section{Life of Bearing (in hours):}

$\mathrm{L}$ (in hours) $=\left(\frac{10^{6} \mathrm{~L}(\text { in million cycles })}{60 \mathrm{~N}}\right)$

Where,

$\mathrm{N}=$ Rotational speed in $\mathrm{rpm}$

From the above calculation the bearing life of Needle roller bearings it is found that $9.65 \mathrm{Hrs}$. 


\section{FEM ANALYSIS OF NEEDLE ROLLER BEARING}

A variety of specializations under the umbrella of the mechanical engineering discipline (such as aeronautical, biomechanical, and automotive industries) commonly use integrated FEM in design and development of their products. For FE Analysis, it is necessary to create a solid model of needle roller bearing and also to create FE model. In present work, static analysis has been carried out for the bearing considering sudden load effects. As shown in figure, CATIA is used for modeling the bearing of ginning.

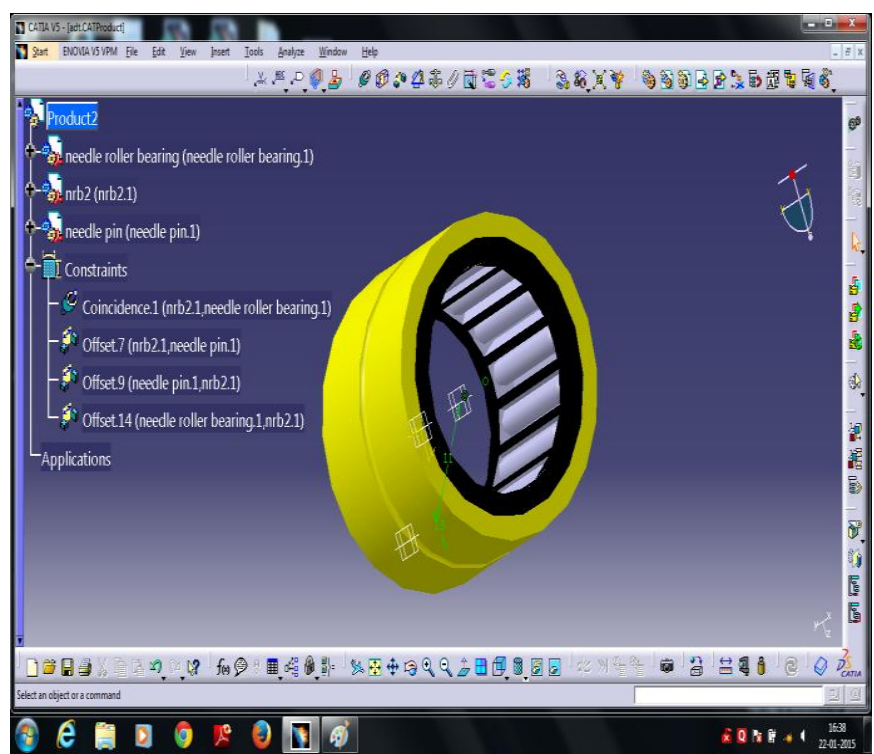

Fig -5: Modeling of bearing

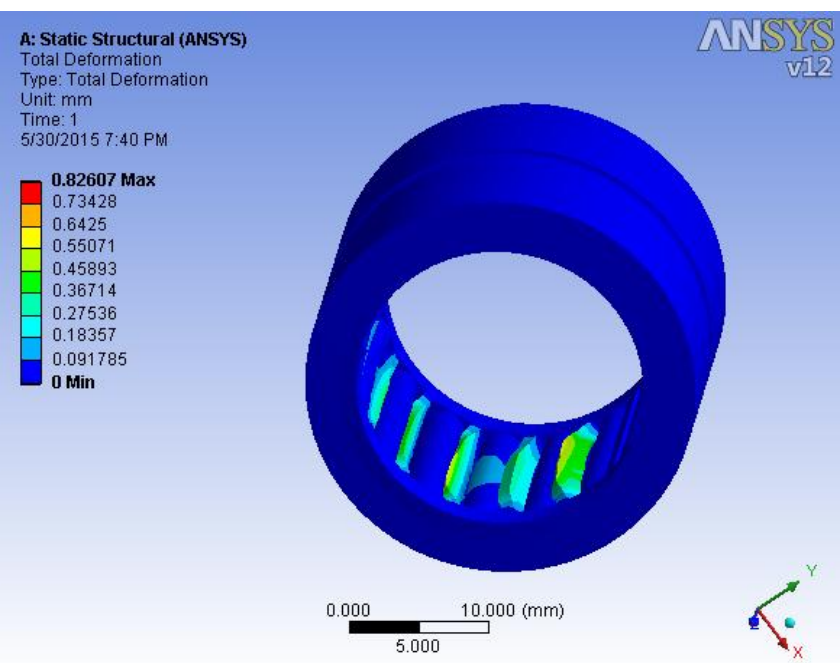

Fig -6: .Total deformation

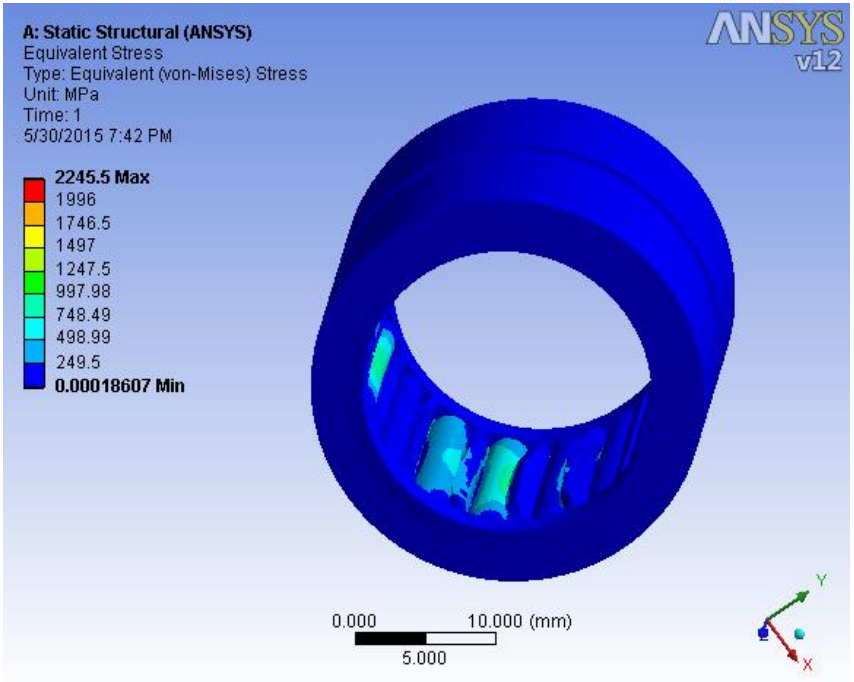

Fig -7: Equivalent stresses

\section{CONCLUSION}

From the above design calculation it is find out that life of the needle bearing is $9.65 \mathrm{Hrs}$. so by design consideration it has to supply the lubricant after every 2 to $3 \mathrm{hrs}$. so it ultimately affects on the production of the industry. Although the stresses comes is under the design stress which it can sustain but it can not live long incase of cyclic repetitive stresses which cause failure in the form of brinelling.

\section{ACKNOWLEDGMENT}

The author would also like to thank M.R. Ginning and pressing factory Talegaon (s. p.) for their contributions to the data and case studies in this paper...

\section{REFERENCES}

[1]. P.B.Kondhia and Prof. P.H.Darji, "Contract stress analysis of needle roller bearing used in synchromesh gear box," in IJTRE, vol. 1, issue 10, june 2014, pp.2347-4718.

[2]. P.bharath,KRaju,M.Vigneshwar and R.Rohit, "Study of ginning and pressing mills," in IJETIE, vol. 1, issue 14, april2015, pp.2394-6598.

[3]. R. K. Upadhyay, L .A. Kumaraswamidhas and Md.SikandarAzam, "Rolling element bearing failure analysis: A case study," in elsevier, (2013), pp. 1517.

[4]. U.A.Patel and R.Shukla,"Vibration analysis of selfalign ball bearing having a local defect through FEA and its validation through experiment,"in IJMER, vol. 2, issue 3, may-junel2012, pp.1073-1080

[5]. H.S.Deshpande,S.S.Kulkarni,B.S.Gandhare, "Investig ation on effect of defect on cylindrical roller bearing by experimental and FEA approach," in IJETAE, vol. 4, issue 6,junel2014,

[6]. TomoyaSakaguchi,"Two dimensional dynamic analysis of cage stress for needle roller bearing that support connecting rod in reciprocating engine," in NTN Technical review, no 79,2011. 
[7]. Jyoti K. Sinha, "Frequent and Premature Failure Of Anti-Friction Bearings: Diagnosis Approach?" 3rd International Conference on Integrity, Reliability and Failure, Porto/Portugal, 20-24 July 2009, pp. 1-8.

[8]. Katsuyuki Kida, Takashi Honda and Edson Costa Santos, "Semi-circular surface cracks and flaking failures in silicon nitride bearings,"Published online by the VBRI press in 2011, pp. 336-340.

[9]. F. Camcia, K. Medjaherb, N. Zerhounib and P. Nectouxb, "Feature Evaluation for Effective Bearing Prognostics,"published in "Quality and Reliability Engineering International", 2012, pp. 1-15

[10]. B. A. Kardile, "Bearing Life Improvement of Centrifugal Blowers by Vibration Analysis," in IJMER, Vol.2, Issue.6, 2012, pp. 4026-4029.

[11]. P.G.patil, P.M.Padole, "Double roller cotton ginning machine: its drawbacks and possible modification," An overview.

[12]. P.G.Patil and VaishaliPatil," Development of prototype double roller gin with improved power transmission and its performance evolution," An overview.

[13]. S.B.Jadhao,S.vanchewaran,N.C.Vijia and K R K iyer,'Roller and beater speed combination for higher lint out turn in double roller gin,"," in IJFTR, Vol.28, Dec 2003, pp. 377-384.

[14]. Dr. H. Hirani, "Failure of Rolling Bearings: An Overview

\section{BIOGRAPHIES}

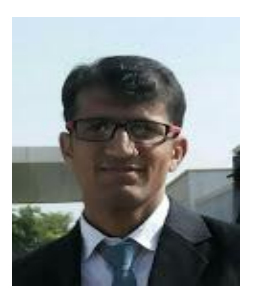

\section{Mr. G.R.NAKHALE}

Lecturer in mechanical dept. P.R.PATIL

POLYTECHNIC Talegaon (s.p.)

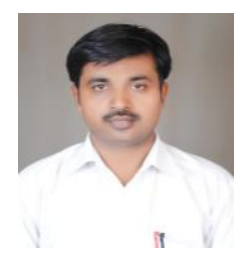

Mr A.D.THAKAREM-TECH Student

(CAD CAM)

DMIETR Wardha

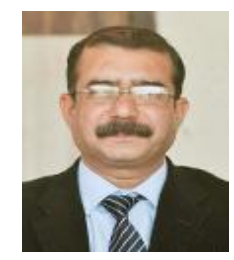

Mr. S.P.UNTAWALE Principal DMIETR Wardha.

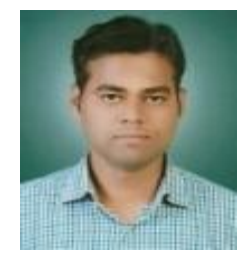

Mr. G.R.NAKHALE Lecturer in Mechanical dept. P.R.PATIL POLYTECHNIC Talegaon (s.p.) 